\title{
ORGANIZATION THEORY AND COMPLEX PEACEKEEPING OPERATIONS: NOTES FROM THE MINUSTAH
}

\author{
João Marcelo Dalla Costa'
}

\section{Introduction}

With the end of the Cold War, the UN developed the so-called complex peace operations and became increasingly involved in peacebuilding, working alongside with other intergovernmental, governmental and nongovernmetnal organizations. Complex peace operations (or complex peacekeeping as known in the Brahimi Report), includes the traditional peacekeeping tasks of interposition and observation, the new functions of elections monitoring, disarmament, demobilization and reintegration (DDR), protecting humanitarian relief workers, and transitional administration (Bellamy, Williams and Griffin 2004) ${ }^{2}$. Due to the great variety and interdependence of actors involved in this kind of mission (military, agencies, NGO's, etc.), the complex peacekeeping offers an opportunity to access how far Organization Theory is able to shed light on the interorganizational coordination in such operations ${ }^{3}$.

The concept of peacebuilding was discussed by Boutros-Ghali in the I992 Agenda for Peace, and was further debated in the 2000 Report of the Panel on UN Peace Operations (most known as the Brahimi Report). The Brahimi Report linked the functions of peacebuilding and peace enforcement to the definition of complex peacekeeping. In this sense, the Brahimi Report defines peacebuilding as: "activities undertaken on the far side of conflict to reassemble the foundations of peace and provide tools for building on those foundations something that is more than just the absence of war" (Brahimi $2000,3)$. On the other hand, Roland Paris suggests a more comprehensive ac-

I Professor at the Doctoral Program of Military Science at Escola de Comando e Estado Maior do Exército (ECEME). Email: jmdallacosta@hotmail.com

2 See also Paris 2004.

3 See Herrhausen 2007 and Lipson 2003, 2005, 2007. 
ademic definition based in the premises laid in the Brahimi Report but more useful to analyse and understand complex peacekeeping: "actions undertaken at the end of a civil conflict to consolidate peace and prevent a recurrence of fighting. A peacebuilding mission involves the deployment of military and civilian personnel from several international agencies, with a mandate to conduct peacebuilding in a country that is just emerging from civil war" (Paris $2004,38)$. Paris' definition observes that peacebuilding is a post-conflict activity, and most importantly, it involves the participation of a range of different actors, therefore recognizing the need for coordination as part of the mission (Paris 1997). In this sense, as much as interorganizational coordination can be seen as a prerequisite to the operation's success, also persistent coordination failures, especially through competition between the different actors in the field, can lead to the collapse of complex peace operations as a whole, and have impacts on future operations (Cooley and Ron 2002). As mentioned in the 2005 Report on Integrated Missions: “(...) the multi-dimensional nature of such an enterprise [post-conflict peacebuilding], thus, demands effective coordination measures". (Eidel et al. 2005)

The UN makes use of a notable number of coordination mechanisms for its peace operations. Those can comprise the use of Special Representatives of the Secretary General (SRSG's), personalities, definition of departments in the UN that stay responsible for the coordination measures (lead departments), deployment and support, the Strategic Framework initiative, Integrated Mission Task Forces (IMTFs), Humanitarian Operations Centres (HOCs), and Civ-Mil Operation Centres (CMOCs/CIMIC). Individual States also contribute to coordination with the development of a group of friends of the peace process, Contact Groups, etc. Nevertheless, the Peacebuilding Commission, the Peacebuilding Support Office and the Peacebuilding Fund also contribute to enhance cooperation in peacebulding (Jones 2002).

Interorganizational coordination is a serious pitfall especially in complex peace operations that involve several actors with different organizational cultures. The UN has developed many mechanisms and techniques to deal with the coordination flaws in complex peacekeeping. The issues of interorganizational cooperation are central to the Organizational Theory, and many branches of Organizational Theory can offer insights and shed light on those pitfalls and flaws. In this sense, the theory suggests that coordination can occur through transmission of common standards in organizational fields (DiMaggio and Powell I99I). Studies based on transaction costs and relational contracting present insights on the circumstances under which coordination using hierarchical structures and instruments are adopted and work well (Weber 2000). On the other hand, principal-agency theory argues that agen- 
cy control problems can discourage coordination in hierarchical structures (Hawkins et al. 2006). Coordination without hierarchy is also analysed by social network theory (Kadushin 20I2). Most studies of peacebuilding in International Relations tend to focus on the relationships between States and Intergovernmental Organizations. They tend to analyse such missions exclusively as a principal-agent problem. They explain coordination problems as caused by a failure of delegation and accountability. This view lacks a more comprehensive understanding of the verticality of complex peacekeeping operations and the great variety of actors involved.

The recognized importance of actors others than intergovernmental organizations to the success of complex peace operations means that an exclusively focus on hierarchical coordination is not able to grasp the complexity of these new kind of relationships. Interactions between various actors such as States, militaries, armed and civilian local actors, regional organizations, international organizations and nongovernemtal organizations must be taken into account if one wants to understand how interorganizational coordination works in complex peacekeeping. Organization Theory approaches both formal and informal paths of interorganizational coordination, thus is more adequate to clarify how the coordination in complex peacekeeping occurs.

This article draws from previous research carried by Michael Lipson, Roland Paris, Thomas Weiss and others. We offer a brief case study of the United Nations Stabilization Mission in Haiti (MINUSTAH), explaining, with the help of Organization Theory, why the cooperation between military and NGO's is efficient to deliver local ownership and increase legitimacy to the mission 4 .

\section{Organization Theory}

Among the different approaches developed by Organization Theory, we will observe in this article the transaction cost economics and network theory. We understand that these two approaches better explain both formal and informal ways of interorganizational coordination. Other Organizational Theory approaches such as resource dependence, contingency theory, organizational ecology and garbage can process can also be tested against our argument in order to achieve the best explanatory power (Fordisck I999).

\section{Transaction Cost Economics}

4 This case study is largely based on interviews with members of the MINUSTAH, National Diplomats and NGOs representatives. 
Central to the field of economic strategy, Transaction Cost Economics addresses basic questions of why companies exist and how they govern operations. In this sense, companies are created to structure and coordinate transactions in a controlled and predictable way. This hierarchical coordination works more efficiently than the market. Therefore we can argue that organizational structures emerge as a consequence of economizing on the costs of arranging and implementing contracts governing exchange. According to Lipson, this logic, employed by International Relation theorists to explain international regimes and security arrangements (Hasenclever, Meyer and Rittberger 1997; Hart 1995), can also be used to understand coordination in peacekeeping. In his words:

This would suggest the hypothesis that the structure of coordination mechanisms should reflect the relative transaction cost efficiency of alternative means of coordinating interorganizational relations in peacekeeping. $\mathrm{Ce}$ teris paribus, where transaction costs of coordination are high, we should expect more hierarchical coordinating mechanisms, such as SRSGs with strong mandates and explicit authority. (Lipson 2007, I5)

Likewise, David Lake (1999) examines the relationship between joint production economies, governance costs, and costs of opportunism; while Katja Weber (2000) observes that transaction costs interact with threat levels to determine how much hierarchy will exist in a security arrangement. Those assumptions suit the case of cooperation among States understood as rational unitary actors. However they are not broad enough to capture the different variety of actors (most of which cannot be included in the narrow category of rational actors, such as NGO's and local actors) included in complex peacekeeping. Those missions are better understood as open systems; therefore, due to the quantity and complexity of interdependent actors involved for the success of the mission, the importance of exchange of information and coordination among themselves and with the environment is fundamental. This suggests that transaction costs approaches, however useful to observe that the degree of hierarchy is in part a function of transaction costs, must be taken prudently.

\section{Social Network Theory}

More fruitful to our discussion on the interorganizational coordination in the MINUSTAH, is the informal coordination through networks of actors participating in the mission. Networks are more flexible than hierarchies. The basic premise of networks is that parties in the relationship are mutually 
dependent on the resources controlled by each other, thus pooling resources can lead to mutual gains (Naim 2003). In this sense, the effectiveness of coordination through networks have become salient with the economic, social and technological changes induced by innovation, higher levels of education, and the culture of cooperation and trust in sectorial industries (Alter and Hage I993). According to Alter and Hage (I993), this new governance mechanism is to increasingly substitute both markets and hierarchies. Because networks are much more flexible than hierarchies, it suits better in situations involving increasingly amount of information, need for rapid responses, reliance on trust, reciprocity and shared understandings, thus enhancing cooperation.

According to Lipson, in complex peacekeeping, much of the interdependence and coordination occur bilaterally (when pair of nodes of a network are strongly coupled with each other) than multilaterally (when organizational nodes are tightly coupled and multiply linked). That is, most coordination occurs in situations when a NGO needs military escort, or when a civil affairs unit needs supply from local sources (Weiss I998). In these cases, informal structures are more adequate (like the CIMIC/CMOCs), while more hierarchical, formal arrangements can be dangerous, or at least dysfunctional, especially in scenarios where principles of consent, impartiality and non-use of force are unstable or inoperative, and the locals perceive one or more actors involved in the mission as part of the problem.

This is not to argue that formal structures are not important for the interorganizational coordination in peacekeeping missions, but that in cases where actors are involved in ongoing, complementary activities and in circumstances that require operational integration, or under conditions of uncertainty about how to obtain desired outcomes, informal networks are more likely to develop. These informal networks normally navigate around formal structures that are inefficient. They can develop when the formal structures present an obstacle, or even block the task to be accomplished for the success of the mission. In these cases, informal networks complement formal arrangements compensating for their weaknesses. In extreme cases, all interorganizational coordination may be carried exclusively through informal arrangements, rendering formal structures merely ceremonial (Alexander I995). This kind of decoupling between interorganizational coordination and formal structures is useful if makes the organizations coordinate better their activities through informal arrangements while keeping the hierarchical (formal) structures intact in order to satisfy political pressures (Brunsson I989).

\section{Interorganizational Coordination in the MINUSTAH}


In February 2004, the Haitian president, Jean Bertrand Aristide, left the country after a series of armed conflicts that started in the city of Gonaives and threatened to spread into the capital city. In April 2004, the UN Security Council passed the resolution I542, which established the fifth UN mission in Haiti, the MINUSTAH, to take over the Multinational Interim Force (MIF). The United Nations Stabilization Mission in Haiti is the last of a series of UN missions in Haiti since I993. The complexity of those interventions increased from peacekeeping to include State and nation building (Aguillar 2002). According to its mandate, the MINUSTAH is responsible for the establishment of a secure and stable environment; assist and support the political process; and monitor and report on the human rights situation (UN 2004). In this sense, the MINUSTAH can be included in the definition of complex peacekeeping presented above due to its tasks that range from restructure the Haitian National Police (HNP), run a DDR process (together with the United Nations Development Programme), foster political dialogue among political actors and assist the government to organize elections, monitor and report human rights violation working in close cooperation with the office of the UN High Commissioner for Human Rights, and deliver basic humanitarian needs to the local population. Thus, the range of actors and the tasks involved in this Mission requires well functioning interorganizational cooperation. This complex peacekeeping mission takes place in a very specific environment where local elites are used to foreign interventions and take profit of it.

The United Nations' organization chart in Haiti resembles pretty much as a ordinary peacekeeping chart: with the Special Representative of the Secretary-General (SRSG) as head of the mission, the Principal Deputy, the elections section, the administration section, the Deputy Special Representative of the Secretary-General and Humanitarian Coordinator, Resident Coordinator and Resident Representative for UNDP; the military commander and the police commissioner (Marcondes 2008). While the chart is very clear, the situation on the ground determines the pace, and how the coordination among all agencies, local actors, and other stakeholders really develop. The one size fits all approach does not work in practise and the peacekeeping operation (PKO) tend to interpret the mandate creatively according to the local specificities, finding the best path to produce bureaucratic problem-solving actions and concrete results for the success of the mission (Rocha 2009).

In an effort to understand the specificities of the local Haitian elites, Antônio Jorge Ramalho da Rocha identifies there are three fundamental principles that organize the Haitian society: short-termism, marronage and authoritarianism. These three principles combined influence economic, political and 
social processes in Haiti. The first refers to the need that results of public policies must be seen immediately, because life is short (life expectancy of 52 years old) and the future is uncertain. The second principle refers to the great informality and ambiguity in social interactions; it also refers to the fact that Haitians do not trust each another and hardly make commitments outside their family circles. The third principle refers to the fact that René Préval was the first and until now the only elected president in the History of Haiti to transfer the power peacefully to another elected president, Jean Bertrand Aristide, in 200I; it also refers to the fact that the political game in Haiti has no clear rules and political parties are created and dissolved according to the leaders' short-term interests and political circumstances. This recalls the idea of predatory republicanism advanced by Robert Fatton (2002), to explain that Haitians see the access to State institutions, through regulatory privileges that favour families and economic groups, as the primary, or the only mean of acquiring wealth and power.

In this environment of short-termism, where everything is perceived as precarious and transitory, the actors strive for survival generating a cycle of fear among political groups. These groups use gangs in order to try to preserve their political influence. The spiral of violence avoids any kind of agreement among political groups and, due to its past record, international intervention is seen as only a topic, transitory and superficial solution. In societies, like Haiti, where violence is seen as legitimate to solve conflicts and settle disputes, this dynamic is perpetuated, exchanging periods of tyranny and of mob rule. Local actors have experience in dealing with foreign interventions, and see them as a possibility to take personal advantage. This also follows a circular logic: political crises are created and solved to keep financial inflows for the advantage of some actors, while the issues are kept unsettled. According to Antônio Jorge Ramalho da Rocha: "As the local elite understand the timing of missions and the persons in charge of the operations, as well as their professional career interests, they manipulate time, make agreements, foster social unrest, depending on the issues on the agenda" (2009, I7). Peacekeeping missions are also scapegoats for local elites that justify the government's inefficacy and gain support among the population, normally telling the people that the country remains under foreign occupation. The degree of legitimacy associated with the local government also reflects the tolerance with the PKO. In the absence of legitimate authorities, spoilers feed the spiral of violence and avoid any possible agreement.

The MINUSTAH operates in this complex environment, which includes also the participation of NGO's, companies that provide different kinds of services, including security, flows of goods, persons and information, and 
under strong media surveillance. Local elites charge donors and the PKO as responsible to address not only the security stabilization but also if not all, most social needs. The PKO is charged and pressured by the local elite, to build basic infrastructure, develop economic public policies, and create jobs, all designed to favour particular sectors of the economy or specific groups. The Haitian elite is experienced and skilful to affirm at the same time State sovereignty and its fragility, depending on the interest at the moment. In this sense they are able to explore the interorganizational flaws in the UN agencies to set the timing at their favour, according to the case, creating changes to justify investments but controlling the final destination of the money at their own favour. In the radio, in créole (the local language), congressmen and members of the Cabinet blame the international community for the actual situation, trying to gain leverage among population and maintaining an ambiguous and risky game. This groom image of the MINUSTAH gains force among the population, as it is asked to repress manifestations and control of social order. After more than ten years of MINUSTAH, the donors and international organizations still see the situation as volatile, while new urgencies that emerge around the globe demand resources and energy. The local population sees the presence of foreign military troops as too long (Rocha 2009).

For this reason, taking into account traditional political practices and understanding how the local society works are fundamental factors for enhancing legitimacy and increasing the chances of success of the mission. The recent experience of cooperation between different actors in the MINUSTAH shows that informal relations are the most effective way to deliver local ownership in an environment populated by a skilful elite, already used to take advantages from international interventions and the social need to see concrete outcomes of the mission in the short-term. Local ownership entails more than just organizing local elections, it represents that the key to the success of complex peacekeeping remains with domestic actors. However the Haitian case, local ownership beyond elections exposes tensions between international norms and domestic realities. The necessity of the Haitians to see the concrete results of the peacekeeping mission in their daily life represents a big challenge to its legitimacy. Nevertheless, the traditional local owners - the local political elite - are the most problematic. In this sense, one possibility to bypass the problem of corrupt local elites is to strength civil society organizations. Domestic civil society can be seen as an alternate set of agents capable of carrying out projects of local ownership, while strengthening the public confidence in the peacekeeping mission (Donais 2008). According to Beatrice Pouligny (2005): "[civil society is] often seen to carry the best hopes for a genuine democratic counterweight to the power-brokers, economic ex- 
ploiters, and warlords who tend to predominate in conflict-ridden, weak, or failed States".

Some caution is needed also not to over-dimension the importance of NGO's to peacebuilding. In some cases empowered and activist civil society organizations can be just like the political elites that engage in factionalized politics (Pendergast and Plumb 2002). Especially in the case of Haiti where donors are faced with weak government institutions, tend to go around the government and prioritize the work with NGO's. Nevertheless, institutional building must be the fundamental objective (International Crisis Group 2009).

However, after legitimacy crises between the departure of Aristide in 2004 and the inauguration of Préval in 2006, the MINUSTAH regained legitimacy especially due to the Préval's election and the successful deliver of humanitarian needs coordinated effectively by MINUSTAH and NGO's. This coordination is done using mostly informal arrangements, which answer more rapidly and effectively the needs of the Haitians, taking into account the local specificities. While the formal long term institution building is carried by UN Agencies, the local delivery of basic social needs is more effective through local and international NGO's. In this sense, the two biggest obstacles to the success in Haiti depend also on the interorganizational capacity of the MINUSTAH to keep developing the "peacebuilding from below", especially carried using informal coordination among military and NGO's; and continue to address the Haitian State's capacity deficit through the formal means of the UN Agencies.

\section{CIMIC and the BRABAT}

In regard to the interorganizational capacity of the MINUSTAH it is fundamental to observe the Civil-Military Cooperation (CIMIC) especially in the Brazilian Battalion (BRABAT). The Department for Peacekeeping Operations (DPKO) defines CIMIC as: “(...) a military staff function that contributes to facilitating the interface between the military and civilian components of an integrated mission, as well as with the humanitarian and development actors in the mission area (...)" (DPKO 20I0). Brazil has not only the military command of the Mission but is also the major troop contributor with I,343

5 “(...) peacebuilding from below seeks to combine the top-down local ownership produced by national-level elections with myriad forms of bottom-up local ownership, in which local-level actors, communities, and organizations become active participants and agents in the peacebuilding process, rather than simply passive recipients of outside interventions." (Donais 2008, I6) 
boots on the ground ${ }^{6}$. The relations between the NGOs and Brazilian troops have been described as "very positive" by some NGOs which previously have been declared skeptical of cooperation with military?.

Each Battalion has its own Civil Affairs Section (G9) which coordinates the CIMIC. The 6-month rotation of the $\mathrm{G} 9$ is a flaw in the long term vision for Mission's interorganizational coordination. In this sense, we observe that each contingent has its own objectives established by the $\mathrm{G}_{9}$ according to the local circumstances. These objectives are in general restricted to the 6-month rotation period. Besides, the lack of qualified personnel working in the CIMIC points to a difficulty to its activity (Cerqueira 20I4). One of the greatest doctrine challenges of the $\mathrm{G}_{9}$ is to present the troops with a clear cut differentiation between CIMIC and Civic-Social activities. Civic-social activities are those short-termed, temporary activities performed exclusively by the military with the objective to solve a urgent social need and win the hearts and minds of the local population ${ }^{8}$. This misconception leads to the error of the military ignoring or duplicating the civilian effort. Besides the intensive training in CIMIC previous to the deployment ${ }^{9}$, informal talks between the military and the civilian components involved in the CIMIC were fundamental to understand the difference between CIMIC and Civ-So Actions. It was also identified that the information included in the Area of Responsibility (AoR) were exclusively target to military and intelligence activities and did not include CIMIC. There was no single document that included CIMIC activities in the AoR in which the military could base their planning. To solve this problem, the Brazilian Army started a new Strategic Study of the Area. This document, aimed at mapping the CIMIC needs to foster coordination, was based in two other documents: the NATO's CIMIC Field Handbook and the Doctrine Coordination Note of the Brazilian Army (N. 02/20I2). Six major fields of cooperation based on the Mission's Mandate were mapped according to the AoR: political, security, economic, social, infrastructure and informa-

6 Figures of May 20I5.

7 Interview with NGOs. Especially the Viva Rio has openly declared their positive cooperation with the brazilian military in Haiti.

8 "A set of non-permanent activies, episodic or of programmed assistance and aid to communities that promote the civic and communitarian spirit of citizens, in the country or abroad that is carried out by armed forces military organizations in the most varied levels of command. It makes use of the human, materail and technical resources available to solve imediate and clear dangers. In addtion to its nature as an aid initiative, it is also inserted as a civilian matter and collaborates in psychological operations." (Manual de Campanha EB2O-MC-IO.20I, Brazilian Army)

9 The pre-deployment training is carried at the Brazilian Peace Operations Joint Training Centre (CCOPAB). 
tion. The document also mapped the main NGOs, IO's (and agencies) and single governments' agencies acting in the AoR. In the final document it was also listed an analysis of the stakeholders; mechanisms, best practices and platforms for civil-military coordination in the MINUSTAH; and CIMIC funding possibilities.

As the Mandate's deadline gets closer (complete withdrawal planed for December 2016) the so-called transition/hand-over phase speeds up with the execution of projects and delivering local ownership to the Haitian population. Two of these projects called our attention because they express how the informal channels of cooperation ease problems of interorganizational coordination in Haiti. The project "Honra e Respeito em Bel Air" (Honour and Respect in Bel Air) is managed by the Brazilian NGO Viva Rio. This project is funded by the governments of Norway and Canada and aims to bring drinking water and waste collection to the poorest parts of Haiti. The NGO used to often require a convoy or military support to carry its activities. According to the Viva Rio coordinators, the military support was decisive for the success of the project, especially in the beginning. Eduarda Hamann, Viva Rio`s former coordinator argued that "(...) there is a strong and permanent interaction with the brazilian battalion”. Viva Rio's founder Rubem César Fernandes agrees with Eduarda Hamann and adds that the cooperation through informal channels and personal contacts with the military component was fundamental for the success of the project. Other project that called our attention was the partnership between the BRABAT and the Child's Pastoral ${ }^{\mathrm{o}}$; the project, mostly funded by the Brazilian government, consists in bringing basic medical care to the Haitian population and promotes a debate within the Haitian government on how to improve the Health System. In this project, the BRABAT helped with the relocation of a IDP camp (Internally Displaced People), offering technical courses, educational talks, and housing.

The practice of informal networking seems to foster mutual trust, enhance interorganizational coordination and speed up the delivery of local ownership to the Haitian population. The G9, realizing that these informal channels were useful, redirected the community demands to the responsible local subunits, thus creating a direct channel between the local population/ NGOs and the subunits' commander, enhancing trust. The order of priority was delegated to the subunit and the G9 became a facilitator, coordinator and advisor to the local subunits, creating a better flow of information and command and control management. The technical courses also became very decentralized, with the local subunits organizing together with the local

ıo Child's Pastoral founder Dra. Zilda Arns Neumann died in Haiti during the 2oro's earthquake. 
community. The consequences of the decentralization were the increasing amount of interactions and informal channels of communications between the subunits and the local population/NGOs with the subsequent enhancement of trust of these actors in the subunit's commander; the simplification of coordination and prioritization of activities; and the empowerment of the local community and the subunit, speeding up the pace of how the local population's demands were addressed.

\section{Final Remarks}

A great variety of organizations take part in peacekeeping and peacebuilding Missions, including UN Agencies, NGO's, militaries, local civil society actors, State actors, etc. We can recognize that these organizations have different and sometimes conflicting views, organizational cultures, missions, etc. Nevertheless, they are dependent, to some extent, on each other to accomplish their individual missions. Therefore, interorganizational coordination is a key element for the success of peace operations.

The organizations involved in peacekeeping and peacebuilding Missions have sometimes distinctive understanding of concepts and norms. These conflicting standards include basic norms of sovereignty, democracy, human rights, local ownership, etc. Peace missions are stark dependent on conformity of the understanding of those norms for its legitimacy. Therefore, if the organizations involved in the Mission lack common understanding or conflict heavily on this normative standards, they will fail to guarantee the necessary support (legitimacy) and resources to successfully accomplish the Mission. In this institutional environment these organizations are evaluated in regard to their adherence to collective standards and norms, ability and efficiency to perform tasks, provide goods, and most of all deliver local ownership.

Based on interviews, primary and secondary literature, we argued in this article that cooperation in the MINUSTAH successfully occurs using informal channels between military and NGO's. The NGO's have a flexible, informal approach and are focused on short-term projects destined to strengthen local ownership. On the other hand, UN Agencies' lack of coordination and the few projects directed to create local ownership from below are caused by the inherent UN's interorganizational complexity and an understandable focus on developing Haitian national institutions.

Finally, it is argued that Organizational Theory offers consistent approaches to understand the complexity of interorganizational cooperation in 
PKOs. The MINUSTAH presents an interesting case for informal cooperation as means to deliver short-term results and increase local ownership. This does not mean that every peacebuilding mission will be the same. However, applying Organizational Theory helps to shed light on factors that may enable or inhibit optimal interorganizational coordination among UN Agencies, the Military and NGO's in regard to the local specificities.

\section{REFERENCES}

Aguillar, Sérgio. 2002. "As forças de paz do Brasil: um balanço." In Brasil e o mundo: novas visões, edited by Clóvis Brigagao and Domício Proenca Jr. Rio de Janeiro: Francisco Alves.

Alexander, E. R. I995. How organizations act together: interorganizational coordination in theory and in practice. Luxembourg: Gordon and Breach Publishers.

Alter, Caroline, and Jerald Hage. I993. Organizations Working Together. Newbury Park: Sage.

Arquilla, J., and David Rosenfeldt. 200I. “The Advent of Netwar.” In Networks and netwars: the future of terror, crime and militancy, edited by John Arquilla and David Rosenfeldt. Santa Monica: RAND.

Bellamy, A., Paul Williams, and Stuart Griffin. 2004. Understanding peacekeeping. Cambridge: Polity Press.

Brahimi, L. 2000. Report of the Panel on United Nations Peace Operations. New York: General Assembly and Security Council.

Brunsson, Nils. I989. The Organization of Hypocrisy: Talk, Decisions, and Action in Organization. New York: John Wiley and Sons.

Castells, M. 1996. The Rise of the Network Society. Oxford: Blackwell Publishers.

Cerqueira, Bruno. 20I4. "Coordenação Civil-Militar em Operações de Paz Multidimensionais." Military Review.

Cooley, A., and James Ron. 2002. "The NGO Scramble: Organizational Insecurity and the Political Economy of Transnational Action." International Security 27 (I): 5-39.

DiMaggio, P., and W. Powell. I991. The new institutionalism in organizational analysis. Chicago: University of Chicago Press.

Donais, Timothy. 2008. "Peacebuilding and the Dilemmas of Local Ownership: the Case of Haiti." Paper presented at the International Studies Association, San Francisco. 
DPKO. 20IO. Civil-Military Coordination in UN Integrated Peacekeeping Missions (UN-CMIC).

Duggan, C. 2004. "UN Strategic and operational coordination: mechanisms for preventing and managing violent conflict." In From Rethoric to Reality in Conflict Prevention, edited by Albrecht Schnabel and David Carment. Lanham: Lexington Books.

Eidel, Espen Barth, Anja T. Kaspersen, Randolph Kent, and Karin von Hippel. 2005. Report on Integrated Missions: Practical Perspectives and Recommendations. New York: UN Office for the Coordination of Humanitarian Affairs.

Fatton, R. 2002. Haiti's Predatory Republic: The Unending Transition to Democracy. Boulder: Lynne Rienner.

Fosdick, Anna. I999. "Using Organization Theory to Understand International Organizations: four models of multilateral decision-making." International Public Management Journal 2 (2A).

Ghali, Boutro-Boutros. 1992. An Agenda for Peace: Preventive diplomacy, peacemaking and peacekeeping. New York: General Assembly and Security Council.

Hasenclever, Andreas, Peter Meyer, and Volker Rittberger, eds. I997. Theories of International Regimes. Cambridge: Cambridge University Press.

Hauge, Wenche, Rachelle Doucet, and Alain Gilles. 2008. Conflict Prevention in a DDR Context in Haiti. Oslo: PRIO.

Hart, O. I995. "An Economist's Perspective on the Theory of the Firm." In Organization Theory: From Chester Barnard to the Present and Beyond, edited by Oliver Williamson. New York: Oxford University Press.

Hawkins, D., David Lake, Daniel Nielson, and Michael Tierney. 2006. "Delegation Under Anarchy: States, International Organizations, and Principal-Agent Theory." In Delegation and Agency in International Organizations, edited by Darren Hawkins, David Lake, Daniel Nielson and Michael Tierney. New York: Cambridge University Press.

Herrhausen, Anna. 2007. "Coordination in United Nations Peacebuilding: A Theory-Guided Approach.” Discussion Paper No. SP IV 2007-301. Berlin: Social Science Research Center.

International Crisis Group (ICG). 2008. "Reforming Haiti's Security Sector." Latin America and Caribbean Report no. 28.

. 2009. "Haiti 2009: stability at risk." Latin America and Caribbean Briefing no. I9.

Jones, Bruce D. 2002. "The challenges of strategic coordination." In Ending 
Civil Wars, edited by Stephan Stedman, Donald Rothchild, and Elizabeth Cousens. Boulder: Lynne Rienner.

Kadushin, C. 20I2. Understanding Social Networks: Theories, concepts and findings. Oxford: Oxford University Press.

Lake, David. 1999. Entangling Relations: American Foreign Policy in Its Century. Princeton: Princeton University Press.

Lipson, Michael. 2003. "Interorganizational Networks in Peacekeeping and Humanitarian Relief: An Institutional Theory Perspective." Paper presented at the American Political Science Association, Philadelphia.

2005. "Interorganizational Coordination in Complex Peacekeeping." Paper presented at the International Studies Association, Honolulu. 2007. "Interorganizational Coordination in Peacebuilding: Perspectives from Organizational Theory." Paper presented at the American Political Science Association, Chicago.

Marcondes, Danilo. 2008. "A participação e a cooperação entre os países do Cone Sul em operações de paz: o caso da MINUSTAH.” Paper presented at the II Encontro Nacional da Associação Brasileira de Defesa (ABED), Rio de Janeiro.

Morneau, J. 2006. "Reflections on the situation in Haiti and the Ongoing UN Mission." In Haiti: hope for a fragile State, edited by Yasmine Shamsie and Andrew Thompson. Waterloo: Wilfrid Laurier University Press.

Naim, Moisés. 2003. “The five wars of globalization.” Foreign Policy (Jan-Feb)

Paris, Roland. I997. "Peacebuilding and the Limits of Liberal Internationalism." International Security 22 (2): 54-89.

. 2004. At war's end: Building Peace After Civil Conflict. New York: Cambridge University Press.

Pendergast, J., and Emily Plumb. 2002. "Building Local Capacity: From Implementation to Peacebuilding." in Ending Civil Wars, edited by Stephan Stedman, Donald Rothchild, and Elizabeth Cousens. Boulder: Lynne Rienner.

Pouligny, Beatrice. 2005. "Civil Society and Post-Conflict Peacebuilding: Ambiguities of International Programmes Aimed at Building 'New Societies'." Security Dialogue 36 (4).

Powell, W. 1990. "Neither Market nor Hierarchy: Networks Forms of Organization." In Research in Organizational Behaviour 12, edited by Barry Staw and Larry Cummings. Greenwich: JAI Press.

Rocha, Antônio Jorge. 2009. “Do Peacekeeping Missions Reinforce State Fail- 
ure? The Case of Haiti." Paper presented at the International Studies Association Conference, New York.

Tschirgi, N. 2004. "Post-Conflict Peacebuilding Revisited: Achievements, Limitations, Challenges." Paper presented at the WSP International / IPA Peacebuilding Forum Conference, New York.

UN. 2004. Resolution 1542. New York: United Nations Security Council.

Weber, K. 2000. Hierarchy Amidst Anarchy: Transaction Costs and Institutional Choice. New York: Albany Press.

Weiss, T. I998. "Humanitarian Shell Games: Whither UN Reform?.” Security Dialogue 29 (I).

. I999. Military-Cievilian Interactions: Intervening in Humanitarian Crises. Lanham: Rowman and Littlefield.

\section{ABSTRACT}

How far Organization Theory can shed light on complex peacekeeping operations, observing the explanatory power and differences among more hierarchically-based approaches and network theory? It also makes the case for further research on why and how local elites, experienced with foreign intervention, hijack international organizations to advance their own interests.

\section{KEYWORDS}

Organization Theory; MINUSTAH; Elites.

Received on July 22, 2015. Approved on February 03, 2016. 